\title{
First report of Amblyomma dubitatum (Acari: Ixodidae) parasitizing the crab-eating raccoon, Procyon cancrivorus (Carnivora: Procyonidae)
}

\author{
Eberhardt $\mathrm{AT}^{1}$, Fernandez $\mathrm{C}^{1,2}$, Zurvera $\mathrm{DA}^{1,2}$, Monje $^{1 D^{1 *}}$ \\ 1 Laboratorio de Ecología de Enfermedades, Instituto de Ciencias Veterinarias del Litoral, Universidad Nacional del \\ Litoral - Consejo Nacional de Investigaciones Científicas y Técnicas (UNL-CONICET), Argentina. \\ 2 Grupo Capibara - Facultad de Ciencias Veterinarias, Universidad Nacional del Litoral. \\ * Correspondence: LD Monje. Laboratorio de Ecología de Enfermedades. Instituto de Ciencias Veterinarias del Litoral \\ (ICIVET Litoral), Universidad Nacional del Litoral - Consejo Nacional de Investigaciones Científicas y Técnicas (UNL- \\ CONICET). RP Kreder 2805, 3080 Esperanza, Santa Fe, Argentina. E-mail: Imonje@fcv.unl.edu.ar
}

Recibido: 1 Abril 2016. Aceptado: 8 Abril 2016. Disponible en línea: 13 Abril 2016.

Editor: S. Nava

SUMMARY. In October 2015, a tick nymph was collected from a male Procyon cancrivorus found dead at the roadside of the National Road 119 near Mercedes city, Corrientes province, Argentina. The nymph collected was morphologically and molecularly identified as Amblyomma dubitatum and it was found infected with the alpha-proteobacterium Rickettsia bellii. To the best of our knowledge, this report constitutes the first record of the $A$. dubitatum - P. cancrivorus association.

RESUMEN. Primer reporte de Amblyomma dubitatum (Acari: Ixodidae) parasitando al aguará popé, Procyon cancrivorus (Carnivora: Procyonidae). En octubre de 2015, una ninfa de garrapata fue colectada sobre un ejemplar macho de Procyon cancrivorus hallado muerto a la vera de la Ruta Nacional 119 en las cercanías de la ciudad de Mercedes, provincia de Corrientes, Argentina. La ninfa colectada fue identificada morfológica y molecularmente como Amblyomma dubitatum, y la misma se encontró infectada con la alfa-proteobacteria Rickettsia bellii. Este reporte constituye el primer registro de la asociación A. dubitatum P. cancrivorus.

Key words: Amblyomma dubitatum, crab-eating racoon, Procyon cancrivorus, Argentina.

Palabras clave: Amblyomma dubitatum, aguará popé, Procyon cancrivorus, Argentina.

\section{Introduction}

Amblyomma dubitatum is a South American tick with most of the records concentrated in the northeast of Argentina, southeast of Brazil, east of Paraguay and northern half of Uruguay (Nava et al., 2010). The capybara (Hydrochoerus hydrochaeris) is the principal host for both immature and adult stages of $A$. dubitatum, but recent findings suggest that small rodents (subfamilies Caviinae and Sigmodontinae) and marsupials (Didelphidae) can be alternative hosts for the larvae and nymphs of this tick (Debárbora et al. 2012; Nava et al. 2010). Adults of $A$. dubitatum were occasionally found in domestic and wild large mammals as cattle, horses, Tapirus terrestris, Mazama gouazou-bira, Tayassu pecari, Axis axis and Sus scrofa (Debárbora et al., 2012; Nava et al., 2010) and all stages of this tick species were recorded biting humans (Labruna et al., 2007; Nava et al., 2010). In addition, $A$. dubitatum has been recently reported as a possible vector of the pathogen Rickettsia sp. strain Atlantic rainforest and also of Rickettsia sp. strain COOPERI, which has unknown pathogenicity but is closely related to the pathogen Rickettsia parkeri (Monje et al., 2015).

Procyon cancrivorus, also known as the crab-eating raccoon or Aguará popé, belongs to the Procyonidae family and it is distributed from Central America to the southern cone of South America. In Argentina, it occurs in several provinces from the northern and central region such as Catamarca, Córdoba, Corrientes, Chaco, Entre Ríos, Formosa, Jujuy, Misiones, Salta, Santa Fe, Santiago del Estero and Tucumán (Barquez et al., 2006). This mammal inhabits different environments, from Chaco to jungle, but always near water courses (Redford and Eisenberg, 1992). Currently, the conservation status of this species in Argentina is classified as vulnerable (Ojeda et al., 2012).

The objective of this study is to report the occurrence of $A$. dubitatum parasitizing $P$. cancrivorus in northeastern Argentina. 


\section{Materials and Methods}

In October 2015, a male $P$. cancrivorus was found dead at the roadside of the National Road 119 in the surroundigs of a bridge over a small watercourse, 50 $\mathrm{km}$ south of Mercedes city, Corrientes province, Argentina (29.36 $\left.36^{\prime} 47^{\prime \prime S} 58^{\circ} 7^{\prime} 7^{\prime \prime} \mathrm{W}\right)$. The site is located in Ñandubay district, part of El Espinal province where the landscape is predominantly soft plain to gently undulating, occupied by lowland forests, savannas and grasslands, now largely converted to agriculture (Burkart et al., 1999). After careful external physical exam, an imma-ture tick (nymph) was recovered from the dead animal and kept in ethanol $96 \%$. The tick collected was taken to the laboratory where it was identified by using the taxonomic keys reported by Martins et al. (2014). The specimen was compared with reference material and it was deposited in the Wildlife Parasite Collection of the Universidad Nacional del Litoral, Esperanza (Santa Fe, Argentina) (Accession number CR00012). Tick species was confirmed by studying the 16S rRNA gene as previously described (Mangold et al., 1998) and the presence of rickettsial DNA was evaluated by gltA PCR (Monje et al., 2016). For this purpose, two tick legs were excised under a stereoscopic microscope and placed in a microtube with $10 \mu$ of TE buffer $(\mathrm{pH} 8.0)$. The sample was then heated at $95^{\circ} \mathrm{C}$ for $20 \mathrm{~min}$ in a thermocycler (Ivema T-18) and stored at $-20^{\circ} \mathrm{C}$ until used. PCR products were checked by electrophoresis in a $1.5 \%$ agarose gel, column purified and sequenced directly in both directions using amplifying primers.

\section{Results and Discussion}

The nymph collected was morphologically identified as A. dubitatum. The diagnostic characters were the punctuations in the scutum (large and deep punctuations in the lateral fields, and smaller punctuations in the central field), cervical grooves (long and well forward of the level of the posterior margin of the eyes) and the number and the length of spurs in Coxa I (two spurs, external spur less than twice as long as internal spur). The 16S rRNA gene reported a sequence of $389 \mathrm{bp}$ for the tick nymph analyzed (KX009409), which was $99.7 \%$ identical to the corres-ponding sequence of $A$. dubitatum (GU301911). The gltA PCR resulted in a sequence of $756 \mathrm{bp}$ (KX009410) which was $100 \%$ identical to the corresponding sequence of Rickettsia bellii (AY375161).

To the best of our knowledge, this report constitutes the first record of the $A$. dubitatum - $P$. cancrivorus association. In addition, the $A$. dubitatum nymph was found infected with $R$. bellii. In a recent study Monje et al. (2015) reported a high prevalence of this bacterium in questing $A$. dubitatum ticks in the same region. Rickettsia bellii has never been associated with human or animal infection; however, it could play a significant role in the ecology of pathogenic rickettsiae by interacting with them within ticks.

In conclusion, this new record is of sanitary relevance since all stages of $A$. dubitatum were recorded biting humans (Labruna et al., 2007; Nava et al., 2010), highlighting the need of eco-epidemiological studies involving wild carnivores and its parasites in Argentina.

\section{Acknowledgements}

This work was funded by Fundación Bunge y Born (FBBEI 24/14) and Universidad Nacional del Litoral (CAI+D 501-2011-0100498LI).

\section{References}

Barquez RM, Díaz M, Ojeda RA. 2006. Mamíferos de Argentina: sistemática y distribución. Sociedad Argentina para el Estudio de los Mamíferos, Tucumán, 359pp.

Burkart RN, Bárbaro N, Sánchez R, Gómez D. 1999. Ecoregiones de la Argentina. APN-PRODIA, 43pp.

Debárbora VN, Nava S, Cirignoli AA, Guglielmone AA, Poi ASG. 2012. Ticks (Acari: Ixodidae) parasitizing endemic and exotic wild mammals in the Esteros del Iberá wetlands, Argentina. Systematic and Applied Acarology 17, 243-250.

Labruna MB, Pacheco RC, Ataliba AC, Szabo MP. 2007. Human parasitism by the capybara tick, Amblyomma dubitatum (Acari: Ixodidae). Entomological News 118, 77-80.

Mangold AJ, Bargues MD, Mas-Coma S. 1998. Mitochondrial $16 S$ rDNA sequences and phylogenetic relationships of species of Rhipicephalus and other tick genera among Metastriata (Acari: Ixodidae). Parasitology Research 84, 478484.

Martins TF, Labruna MB, Mangold AJ, Cafrune MM, Guglielmone AA, Nava S. 2014. Taxonomic key to nymphs of the genus Amblyomma (Acari: Ixodidae) in Argentina, with description and redescription of the nymphal stage of four Amblyomma species. Ticks and Tick Borne Diseases 5, 753770 .

Monje LD, Costa FB, Colombo VC, Labruna MB, Antoniazzi LR, Gamietea I, Nava S, Beldomenico PM. 2016. Dynamics of Exposure to Rickettsia parkeri in Cattle in the Parana River Delta, Argentina. Journal of Medical Entomolology, doi: 10.1093/jme/tjv250.

Monje LD, Nava S, Eberhardt AT, Correa Al, Guglielmone AA, Beldomenico PM. 2015. Molecular detection of the human pathogenic Rickettsia sp. strain Atlantic rainforest in Amblyomma dubitatum ticks from Argentina. Vector Borne and Zoonotic Diseases 15, 167-169.

Nava S, Venzal JM, Labruna MB, Mastropaolo M, Gonzalez EM, Mangold AJ, Guglielmone AA. 2010. Hosts, distribution and genetic divergence (16S rDNA) of Amblyomma dubitatum (Acari: Ixodidae). Experimental and Applied Acarology 51, 335-351. 
Ojeda RA, Chillo V, Diaz Isenrath G. 2012. Libro Rojo de Mamíferos Amenazados de la Argentina. Sociedad Argentina para el Estudio de los Mamíferos.

Redford, K.H., Eisenberg, J.F., 1992. Mammals of the Neotropics. The Southern cone: Chile, Argentina, Uruguay, Paraguay. University of Chicago Press, Chicago III. 